\title{
СУЧАСНИЙ РОЗВИТОК ДУХОВНОСТІ: МОРАЛЬНІ НОРМИ ТА ПРИНЦИПИ
}

\begin{abstract}
H.I. Гітун
Одним із чинників духовного відродження нашої країни є моральність, яка визначається правилами і нормами моральної поведінки та моральної культури. Моральна оцінка людини формується з позиції добра і справедливості, із виробленого народом поняття моралі: моральний той, хто цнотливий, шляхетний, доброчесний, праведний, людяний т.ін. 3 традиційно-християнської точки зору сутність морального виховання полягає в тому, що людина розвиває і утверджує в собі природну схильність до добра та готовність відстоювати його в собі і в навколишньому житті. Це виховання зорієнтоване на засвоєння людиною абсолютних вічних норм співжиття, які мають універсальний, вселюдський характер і являють собою вияв людяності. Моральність людини позначається на трьох головних

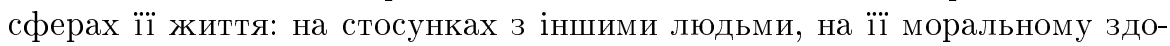

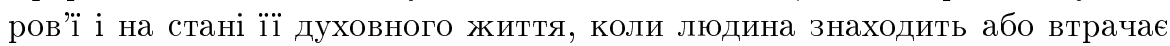
духовну рівновагу.

На наш погляд, моральність у різних народів має свої особливості. Ми поділяємо думку Г. Ващенка, який вважає, що мораль розвивається як і мислення ${ }^{1}$, в якому відбиваються загальнолюдські норми. Проте різні народи і раси по-різному користуються цими нормами. По-різному інтерпретуються і загальнолюдські ідеали. Чим конкретніший рівень інтерпретації загальних законів, тим специфіка її у різних народів відчувається все сильніше. Саме із конкретизації починається і спотворення моралі. Прикладом цього може бути брахманська мораль, що припускає кастовість у суспільстві; мораль мусульманська визнає культ помети і багатоженство; у християнській моралі це відбилося в інквізиції.
\end{abstract}

У сучасних умовах розвитку людської спільноти надзвичайно гостро

${ }^{1}$ Ващенко Г. Виховний ідеал.-2-е вид., Брюссель, 1987.-С. 34-35, 78, 79, 111.

Актуальні проблеми духовності

(Відп. ред.: Я.В. Шрамко)

Кривий Ріг (2005), 89-94 
відчуваються занепади і навіть пустота у сфері моралі. Тому і зростає потреба кардинальної зміни відношення людства до духовності, моральності, моралі. У всіх сферах суспільного життя зростає, зокрема, роль моральної відповідальності особистості. Моральна свідомість особистості найкраще проявляється в $\dddot{11}$ «активній життєвій позиції». Справжня мораль - це мораль активної діяльності. Чим вища зрілість особистості, тим міцніша її моральна свідомість і самосвідомість, і чим глибший, багатший моральний світ людини, тим вища її громадянська відповідальність.

Сучасний суспільний розвиток вимагає формувати духовність кожної людини і суспільства в цілому. Цей процес передбачає виховання та самовиховання в людині непримиренності до будь-яких відхилень від норм моралі, всього, що гальмує духовно-моральний прогрес суспільства. Розвиток духовності зумовлює все більшу активізацію ролі і значення формування у свідомості людської спільноти моральних цінностей. I важливо, щоб ці цінності перетворювалися у невід'ємну рису психології людини, її морального обличчя, служили критерієм оцінки та регулятором поведінки особистості, її моральної зрілості. У всіх сферах моралі-моральній свідомості і моральних відносинах, моральній культурі і моральній практиці, моральних почуттях, формуванні морального ідеалу - роль та значення моральних принципів і норм дедалі більше зростає.

Величезні зміни у суспільних відносинах, що відбулися на початку XX століття, спричинили собою цілий ряд змін у духовному житті. Особливо це відбилося на розумінні моралі. Мораль обслуговувала ідеологію і тому дістала назву «комуністична мораль». Поняття «моральності» штучно звужувалося і зводилося до розумінні зовнішньої поведінки людини. Сама мораль трактувалася опосередковано і людина отримувала право «удосконалювати» й уточнювати ㄲï згідно з потребами ідеології, вказівками вождів, а деколи і з власними потребами.

Така ідеалізована мораль суперечила сутності природи моралі нашого народу, котрий християнсько-етичні моральні цінності завжди ставив на перше місце. Сучасне духовне відродження українською народу передбачає і навіть вимагає повернення моралі до її природовідповідності ${ }^{2}$. Видатний український педагог В. Сухомлинський вважав, що «у невичерпному джерелі народної моралі нам треба черпати духовну енергію справжньої людяності, дружби, товариськості, справжнього братства вільних людей» ${ }^{3}$. Чи можна актуальніше сказати тепер, чого бракує нашому суспільству? Попри всю незабезпеченість матеріальних потреб, брак духовності є найбільш відчутним, нагальним, глобальним і вкрай чуттєвим. Сьогодення вимагає повернення до природних народних моральних дже-

\footnotetext{
${ }^{2}$ Вищневсъкий О. Сучасне українське виховання. Педагогічні нариси. - Львів, 1996.- C. 27 .

${ }^{3}$ Сухомлинсъжий В.О. Моральні заповіді дитинства і юності.-К., 1966.-С. 46.
} 
рел.

Людська душа осягає моральні якості-Віру, Надію, Любов - через три властивості душі: розум, волю і почування. Завдяки почуванням людина сприймає, стикається 3 навколишнім світом видимим і невидимим, природним і соціальним. Через розум проходить аналіз і синтез сприйнятого, він відтворює і спричинює всі вказівки щодо дій, породжених почуваннями. I тільки вивільнена воля спонукає до діяльності, дії чи вчинку, які, в свою чергу, несуть у собі добро чи зло. Саме через діяльність людини витворюється норма дії, поведінки і навіть думки. Набір таких норм і творить мораль. У християнстві вони включають такі норми, які наповнені добром, які становлять суть християнської моралі.

Віра як прояв людського духу багатогранна. Це форма і спосіб сприйняття соціальної інформації, норм, цінностей та ідеалів суспільного життя, які не $є$ практичним чи пізнавальним досвідом, приймаються як очевидні факти чи характеристики об'єктивної дійсності, сущого і належного. Ченці-пустельники вирушали в глухі усамітнені місця (ліс, гори, печери, пустині), вірячи, що саме там на них чекає успіх у боротьбі з гріхами і пристрастями. I. Кант у «Критиці чистого розуму» стверджував, що навіть у пізнанні звичайних речей присутній елемент віри. Одне слово, свій вихідний імпульс будь-яка праця людська дістає у вірі, у можливості успіху на обраному напрямі. Віра, як така, проявляється і як віра людини у саму себе, у свої сили і в саме життя.

Від загальнолюдської віри для моральної людини природний перехід до віри релігійної. Християнська віра, насамперед, існує не окремо, тобто як віра сама по собі, а у тісному взаємозв'язку з почуттям любові і пошани, з почуттям скромності і послуху. Саме з віри починається моральне життя людини. Вона є основним ключем до всієї моральної доброчесності. Давно зауважено, що віра, загалом, є дуже сильним чинником життя людини, допомагає їй переборювати великі труднощі, навіть тортури.

Сучасний етичний релятивізм, носієм якого часто постає телебачення, кіно, преса спричинив руїну віри у вищі ідеали. Не дивлячись на те, що йде відбудова та спорудження церков, вшанування великих християнських свят, залучення видатних священнослужителів до освячення видатних державних актів, все ще можна побачити занепад віри і традиційних цінностей. Спостереження показують, де байдуже ставляться до віри у моральні ідеали, відбувається процес дегуманізації людини.

Віра завжди у єдності з надією і любов'ю, породжує сподівання. Надія вказує на перспективу і забезпечує їі здійснення, надія - це оптимізм, потяг до гармонії, це одна із форм сприйняття майбутнього у духовному житті людини, де бажане, потрібне чи необхідне бачиться й очікується як реальність, що повинна здійснитися. Надія - це є вияв твердості і міцності віри. 
Жива віра сполучається з любов'ю. У любові знаходить вияв некорислива і самовіддана спрямованість на певний об'єкт, відмова від егоїстичних нахилів, потреба до об'єднання і зближення людей. Любов може бути спрямована на особистість, етнічну і соціальну спільність людей, на різноманітні об'єкти пізнання і практичної діяльності: до природи, до життя, до ідеї і т.д. Любов є діяльна, коли вона з'єднує людей, духовно-морально їх збагачує. Всі інші сили, що єднають людей, не є такими сильними як любов. Без любові тривало єднати людей не можуть ні спільність мови, звичаї і спосіб життя, ні племінна чи навіть кровна спорідненість. Без любові зв'язок між людьми зовнішній, механічний. I тільки любов творить внутрішній, духовно-моральний, довготривалий істинний Зв'язок.

Певні моральні якості особистості охоплюють не тільки внутрішній духовний світ людини, а можуть бути виражені, виявлені у безпосередній взаємодії та впливі на них соціального. Вони є індикативними регуляторами стосунків між людьми. Через них та їхні антиподи приходить усвідомлення і розмежування морального і неморального. Найбільш характерні із них - чесність, справедливість, довіра і взаєморозуміння. Усі вони характеризують певний стан людської душі відносно інших людей.

Довіра зумовлюється певним ставленням до людини, яке випливає 3 твердого переконання у відданості спільній справі, вірності, порядності, чесності і відповідальності. Вона необхідна у стосунках між людьми, у їхніх взаєминах. Вміння говорити правду, не приховувати від інших і від самого себе істину факту. Нагальна потреба мати правильне уявлення про навколишній світ і суспільство, у якому живе людина, про вчинки оточуючих, що потребують аналізу, вміти оцінювати життєві ситуації, у які потрапляє особа.

Мірилом людської порядності постає праця; вона $є$ основою культури людських відносин, засобом формування людського єства особистості. Максимально олюднена, одухотворена, свідома праця приносить добро людям, суспільству, народу, Батьківщині. Праця - першооснова життя суспільства, вона має неоціниму виховну силу і $€$ найвищим мірилом цінності людини. У праці формуються такі моральні цінності особистості, як повага до людської праці, доброта і чуйність, вимогливість до себе та інших, відповідальність тощо. Праця $є$ підставою гармонії людини 3 середовищем, засобом її морального самовдосконалення, джерело щастя.

Хліб як головний результат людської праці є символом достатку і щедрості, одним із моральних символів України. Праця і хліб завжди нерозривні з землею-годувальницею. Саме у матері-землі через працю асоціюється поняття любов до землі, любов до рідного краю, любов до Вітчизни. Любов до Батьківщини в українського народу пов'язана з глибокою релігійністю, і вона залишалася найважливішою рисою ідеальної людини у 
поглядах українців. Щирий патріотизм українського лицаря будив у ньому готовність віддати за Батьківщину своє життя - це було лицарською честю і славою. Дружба і побратимство наповнювало всю Запорозьку Січ.

Ми зупинилися на інтегральних моральних чеснотах, що у сукупності своїх ознак можуть найповніше характеризувати моральне ядро особистості. Вони відображають ставлення особистості до самої себе, до інших людей, до природи, до соціальних процесів і явищ, до світу в цілому і буття взагалі; знаходять свій вияв у почуттях, волі, у роздумах ${ }^{4}$; розкривають критерії вихованості з емоційного, вольового та інтелектуального боків і зумовлюють дії і вчинки людини. Осердям моральних чеснот $є$ віра, надія і любов як властивості людської душі. Віра, надія, любоввідчинені «двері» душі людської, через які вона спілкується із світом. Позбавити людину цих чеснот - означає закрити від неї світ.

Моральні чесноти - це місткі, емоційно-образні узагальнення провідних соціокультурних орієнтацій, що визначають усі сфери життя людини. Вони виявляються у всіх сферах людського буття. У житті кожного індивіда вони ж визначають сенс його існування, завдяки ним людина долучається до вищої інстанції, що наповнює сенс її існування, надає йому конкретики. Зміни, що відбуваються сьогодні у світі, екологічна криза $з$ усією наочністю довели, що технологічний розум веде людство до загибелі. Знову на порядку денному постала проблемі моралі. Знову потрібно вводити безмежний оптимізм людської самовпевненості в рамки етичного закону. Отже сучасна мораль ставить певні вимоги:

1. Для внутрішнього життя людини властива постійна конфліктність. I виникає вона від постійних протиріч людської природи. Якщо духовність підпорядкована голосу тіла, тоді і вона матеріалізується, а людина стає в'язнем, рабом матеріального існування. Духовність меркне, зникає. Якщо законодавчою і контролюючою є духовність, то людина високоморальна і морально довершена. Тоді виконується перша моральна вимога - панування нашого духу над матеріальними потребами людської природи і безперервне вдосконалення людської духовності і моралі.

2. Людина істота моральна, що потребує людської спільноти для свого розвитку. Вона ніколи не змогла б засвоїти мови, відчути себе особистістю, мати самосвідомість і потяг до людей, аби від народження жила ізольовано. Людина не стала б на шлях морального розвитку, бо відсторонення від людей веде до виродження серця, недорозвиненості розуму та до нерозкритості духу. Тільки серед людей і у спілкуванні з ними розкривається вся глибина благочестя, основною

\footnotetext{
${ }^{4}$ Рубинштейн С.Л. Бытие и сознание.-М., 1957.-С. 262.
} 
сутністю якої є любов між людьми. Без правдивої, істинної любові до ближнього неможливий ні повний і гармонійний розвиток людини, ні людської спільноти в цілому. Тому любов до ближнього, любов до людей є другою вимогою моралі.

3. Третьою є вимога переорієнтації, повернення до релігійно-моральних начал і безперервного релігійно-морального зростання. Традиційною і загальноприйнятою релігією українського народу є християнство. Людське життя християнство трактує, як безперервний процес релігійно-морального відродження, зростання. Усе повинно цьому служити: і милосердя, і любов, і покаяння, і піст, і молитва, і благочестя. Християнство вчить, що зростання $є$ і моральне, i духовне тоді, як:

- усяку справу в житті робиш не заради того, щоб вчинити, а заради внутрішнього морального росту, яким збагачує людину будь-яка праця на землі;

- сила зла гине в людині настільки, як процвітає у ній добро і благочестя;

- релігійно-моральне зростання, будучи безперервним, забезпечує людині загальноморальні успіхи і виконання свого призначення на землі.

4. Четверта вимога моралі: наша мораль повинна бути пов'язана із державою, у якій живемо, з народом, до якого належимо. Суспільство для людини починається з сім'ї, вона $є$ його первинним осередком. У сім'ї закладаються основи правильного, нормального ставлення до життя, до праці, до людей не тільки у родині, а й до сусідів, колег по роботі, знайомих, товаришів. Щирі, дружні, добрі відносини до всіх переростають у такі ж відносини до всіх людей своєї країни, до кращих сторін їхнього способу життя. Правильно вихована і добре освічена, працелюбна людина завжди відчуває моральний зв'язок з усіма народами своєї Вітчизни. Вся історія народу - це їі історія. Вона любить цю історію. Остання допомагає їй краще зрозуміти сучасний духовний стан свого народу.

Отже, моральний закон вимагає від людини нашого часу бути духовною, любити людей, мати високу мораль, бути патріотом свого народу, сприяти росту духовності у суспільстві. 